\title{
PEMBUATAN DODOL SUSU
}

\author{
Agus Nuroso, S.TP \\ Dosen Teknologi Pangan Faperta UNISI \\ ponyomr@yahoo.co.id
}

\begin{abstract}
Abstrak
Susu dapat diolah menjadi berbagai produk olahan, diantaranya dodol susu. Dodol susu adalah salah satu produk olahan susu dengan penambahan gula, tepung ketan, tepung tapioca, dan santan melalui proses pemanasan pada susu segar atau yang kurang segar. Jadi dodol susu merupakan salah satu solusi untuk mengatasi berlimpahnya produksi susu disuatu daerah. Proses pengolahannyapun tidak sulit dan prospek pemasarannya cukup menjanjikan, mengingat dodol disukai anak-anak maupun orang dewasa.

Dodol merupakan campuran dari susu dengan tepung beras ketan, santan kelapa dan gula sehingga dihasilkan produk makanan yang kenyal dengan rasa manis denga aroma susu. Pembuatan dodol susu bertujuan untuk penganekaragaman pangan, meningkatkan nilai ekonomis, memperpanjang masa simpan, serta mempertahankan dan memperbaiki mutu gizi susu.

Dodol termasuk salah satu bahan pangan, maka keamanan dan keawetan harus terjamin, dimana dodol tidak beracun, tidak mengandung bakteri dan logam yang berbahaya, serta tidak mengandung jamur.
\end{abstract}

\section{PENDAHULUAN}

\section{Latar belakang}

Susu merupakan hasil eksresi normal kelenjar susu dari hewan menyusui atau manusia untuk makanan untuk anaknya. Meskipun susu pada umumnya dapat dihasilkan oleh hewan menysusui, namun yang dikonsumsi manusi di Indonesia khusunya adalah susu sapid an kambing. Susu dari hewan lain yang juga kadang-kadang digunakan untuk konsumsi manusia, diantaranya adalah susu kerbau, susu domba, susu unta susu kedelai. Istilah susu khususnya diartikan diartikan sebagai susu sapi, seangkan susu dari hewan lain ditambahkan nama hewan yang bersangkutan, misalnya susu kambing, sus domba dan sebagainya.

Susu dapat diolah menjadi berbagai produk olahan, diantaranya dodol susu. Dodol susu adalah salah satu produk olahan susu dengan penambahan gula, tepung ketan, tepung tapioca, dan santan melalui proses pemanasan pada susu segar atau yang kurang segar. Jadi dodol susu merupakan salah satu solusi untuk mengatasi berlimpahnya produksi susu disuatu daerah. Proses pengolahannyapun tidak sulit dan prospek pemasarannya cukup menjanjikan, mengingat dodol disukai anak-anak maupun orang dewasa.

\section{Tujuan}

Pembuatan dodol susu ini bertujuan untuk dapat mengolah susu menjadi produk dodol dengan kriteria hasil warna coklat, rasa manis, aroma susu, dan tekstur kenyal. 


\section{KARAKTERISTIK BAHAN}

Bahan dasar yang digunakan untuk membuat dodol adalah susu cair segar maupun sudah agak rusak, dan ditambahkan bahan-bahan lain seperti santan, tepung ketan, dan gula, sebagai bahan pendukung. Sehingga dalam pembuatan dodol susu sebaiknya digunakan bahan-bahan yang berkualitas baik, agar diproleh produk dodol yang baik.

Tabel 1. Syarat mutu Dodol Garut menurut Standar Industri Indonesia

\begin{tabular}{|c|l|l|}
\hline No. & \multicolumn{1}{|c|}{ Komponen } & \multicolumn{1}{|c|}{ Persyaratan } \\
\hline 1. & Bau & Normal \\
\hline 2. & Rasa & Normal \\
\hline 3. & Kadar Air & Maks 30 $(\% \mathrm{~b} / \mathrm{b})$ \\
\hline 4. & Kadar Sukrosa & Min $45(\% \mathrm{~b} / \mathrm{b})$ \\
\hline 5. & Kadar Protein & Min 3 $(\% \mathrm{~b} / \mathrm{b})$ \\
\hline 6. & Kadar Lemak & Min 7 $(\% \mathrm{~b} / \mathrm{b})$ \\
\hline 7. & Kadar Abu & Maks $1 . .5(\% \mathrm{~b} / \mathrm{b})$ \\
\hline 8. & Camaran Mikroba & Maks 5 x 100 \\
\hline
\end{tabular}

Sumber : Standar Industri Indonesia, No. 1616-85.1990

\section{Susu}

Susu sebagai bahan makanan, tidak dapat disngkal lagi merupakan bahan makanan yang sempurna, karena mengandung zat-zat gizi yang sesuai dengan kebutuhan manusia. Selain itu seluruh kandungan zat gizi tersebut akan dapat diserap oleh tubuh manusia.

Susu adalah cairan betbentuk koloid agak kental berwarna putih sampai kuning, tergantung dari jenis hewan serta makanannya dan jumlah lemaknya. Dalam jumlah besar susu kelihatan berwarna putih atau kuning padat (opaque), tetapi dalam suatu lapisan klihatan transfaran. Susu yang telah dipisahkan lemaknya, atau kadar lemaknya rendah, kelihatan kebirubiruan.

Susu rasanya sedikit manis bagi kebanyakan orang, baunya agak harum atau bau khas susu. Jika kena udara mangalir atau dipanaskan kadangkadang baunya hilang. Dibawah mikroskop susu terlihat seperti cairan yang mengandung butiran-butiran.
Butiran-butiran tersebut terdiri dari lemak. Besarnya butiran-butiran lemak susu berbeda-beda mulai dari 0.1-22 mikron garis tengah.

Susu terdiri atas dua lapisan yang dpat dipisahkan yaitu kepala susu atau krim dan skim. Krim adalah bagian yang lebih ringan dari skim, terdapat dibagian atas susu. Bagian krim ini akan kelihatan jikan susu yang barudiperah dibiarkan kira-kira 20-30 menit, maka bagian krim tersebut akan mengapung pada permukaannya. Tergantung dari jumlah dan lemak didalamnya, volume krim kira-kira antara 12-20 persen dari volume susu. Sebagian besar yang terkandung didalam krim adalah lemak. Skim adalah bagian bawah krim, terutama terdiri dari air dan protein.

Susu mengandung berbagai bahan disamping air. Oleh krena itu berat jeinsnya lebih berat dari pada air. Berat jenis susu umumnya berkisar antara $1.027-1.035$ pada suhu $15.5^{\circ} \mathrm{C}$. berat jenis ini dipengaruhi oleh beberapa factor diantaranya jumlah kandungan bahan yang terdapat didalamnya. 
Titik beku susu lebih rendah dari air. Air membeku pada suh $0^{0} \mathrm{C}$, sedangkan susu membeku pada suhu rendah sekitar -0.55 sampai $-0.61{ }^{\circ} \mathrm{C}$. hal ini disebabkan adanya bahan yang larut dalam susu, misalnya gula laktosa dan mineral-mineral. Lemak dan protein berpengaruh kecil terhadap titik beku susu. Oleh kerena bahan yang larut seperti laktosa dan mineral tersebut kadarnya kecil, maka titik beku susu hamper konstan. Hal ini dapat menujnukkan kemungkinan apaan susu tersebut apakah susu tersebut ditambahkan air atau tidak. Menurut percobaan penambahan satu persen air akan menaikkan titik beki kira-kira $0,0055^{\circ} \mathrm{C}$. titik didih susu sedikit lebih besar dari air, yaitu sebesar $100,17^{0} \mathrm{C}$.

Susu sebagian besar terdiri dari air, di samping tiu juga zat-zat lain seperti lamak, protein, karbohidrat, vitamin dan mineral. Perbedaan komposisi rata-rata beberapa macam susu dapat dilihat pada Tabel 2 .

Tabel 2. Komposisi Rata-rata Beberapa Macam Susu

\begin{tabular}{|l|c|c|c|c|}
\hline \multirow{2}{*}{ Komposisi } & \multirow{2}{*}{ Satuan } & \multicolumn{3}{c|}{ Macam Susu } \\
\cline { 3 - 5 } & & Sapi & Kerbau & Kambing \\
\hline Air & $\%$ & 88,3 & 73,8 & 85,9 \\
\hline Protein & $\%$ & 3,2 & 6,3 & 4,3 \\
\hline Lemak & $\%$ & 3,5 & 12,0 & 2,3 \\
\hline Karbohidrat & $\%$ & 4,3 & 7,1 & 6,6 \\
\hline Kalsium & $\mathrm{Mg} / 100 \mathrm{~g}$ & 143,0 & 216,0 & 98,0 \\
\hline Fosfor & $\mathrm{Mg} / 100 \mathrm{~g}$ & 60,0 & 101,0 & 78,0 \\
\hline Besi & $\mathrm{Mg} / 100 \mathrm{~g}$ & 1,7 & 0,2 & 2,7 \\
\hline Vitamin $\mathrm{A}$ & $\mathrm{SI}$ & 130,0 & 80,0 & 125,0 \\
\hline Vitamin $\mathrm{B}_{1}$ & $\mathrm{Mg} / 100 \mathrm{~g}$ & 0,30 & 0,04 & 0,06 \\
\hline Vitamin $\mathrm{C}$ & $\mathrm{Mg} / 100 \mathrm{~g}$ & 1,0 & 1,0 & 1,0 \\
\hline
\end{tabular}

Sumber :Direktorat Gizi Departemen Kesehatan RI (1972)

\section{Gula}

Pada pembuatan dodol diperlukan dua macam gula, yaitu gula merah dan gula pasir. Gula merah yang digunakan berasal dari gula aren atau gula kelapa yang berwarna kuning kecoklatan, bersih tidak mengandung kotoran yang akan merusak kenampakan dodol nana yang dibuat. Sedangkan gula pasir yang digunakan putih dan bersih, supaya dodola yang dihasilkan bersih dan manis. Gula dalam pembuatan dodol berfungsi sebagai :

a. Pemberi rasa manis

Buah nana yang masih mengkal atau setengah matang biasanya memiliki rasa asam. Oleh karena tiubuah nanas yang akan diolah menjadi dodol perlu ditambahkan gula, sehingga dodol rasanya menjadi manis.

b. Zat pengawet

Dalam pembuatan dodol, dapat berfungsi sebagai pengawet, hal ini menyebabkan mikroba tidak dapat tumbuh. Dengan kadar gula yang itnggi, maka aktifitas mikroba dapat terhamabat, sehingga gula dapat mengikat tekanan osmosis pada larutan yang akan menyebabkan plasmolisis merupakan peristiwa keluarnya air dari sel mikroba, hal ini dkarenakan dinding sel mikroba 
brsifat permiabel, dan karena terjadinya perbedaan tekanan antara cairan sela mikroba akan ditarik keluar oleh larutan gula dan sebaliknya gula akan mengganti tempat cairan sel mikroba yang mengakibatkan air yang dibuthkan untuk tumbuhnya mikroba tidak tersedia (sel mikroba menjadi kering) atau Aw (Water activity) bahan akan menurun, dan selanjutnya aktifitas mikroba menjadi terhambat dan bahkan mikrobanya sampi mati.

\section{Tepung Beras Ketan}

Tepung beras ketan (Oryza sativa Glutinsa) merupakan salah satu bahan pendukung dalam pembuatan dodol, yaitu sebagai bahan pengisi atau bahan pendukung dalam pembuatan dodol. Ada beberapa perbedaan antara beras biasa denga beras ketan dalam penempakannya. Beras biasa biasanya mempunyai tekstur yang keras dan transparan, sedangkan beras ketan tekstur lebih rapuh, warnanya putih dan butirnya besar (Grits, 1975 dalam indriafitri, 2000).

Jika ditinjau dari komponen penyusun pati, beras ketan memiliki kandungan amilopektin relative lebih banyak daripada amilosa. Perbandingan kadar amilosa dan amilopektin sangat mentukan sifat dan hasil pemasakan, seperti tekstur dan sifat mengkilat. Pemasakan akan mengubah sifat beras ketan menjadi sangat lekat, mengkilat dan tidak berubah dalam penyimpanan beberapa jam hingga beberap hari (Araulio, 1976, dalam indrafitri, 2000). Tepung beras ketan merupakan bahan pengental yang peling efktif dibandingkan dengan tepung maizena yang mempunyai kandungan amilopektin tinggi.Tepung beras ketan , tepung beras ketan dan tepung maizena tidak memperlihatkan kestabilan yang sama dalam fungsingya sebagai bahan pengental.

\section{Santan}

Santan kelapa merupaka emulsi minyak dalam air $(\mathrm{O} / \mathrm{W})$ yang berwarna putih. Santan dapat diperoleh dengan cara memeras daging kelapa yang telah diparut atau dihancurkan, dengan atau tanpa penmbahan air. Perbedaan dalam teknik pemerasan parut kelapa akan menyebabkan perbedaan rendmen ekstraksi santan yang diperoleh.

Penggunaan santan dalam pembuatan dodol nanas dimaksudkan untuk memberikan rasa lezat dan gurih pada produk. Rasa gurih ini didukung oleh kandungan lemak dalam santan yang cukup tinggi sekitar $34,30 \%$ selain lemak, santan juga mengandung unsur gizi lain seperti terlihat pada Tabel 3 .

Tabel 3. Nilai Gizi Santan Kelapa

\begin{tabular}{|l|c|c|}
\hline \multicolumn{1}{|c|}{ Komponen Gizi } & Santan Murni & + Air (1:1) \\
\hline Protein & 4,20 gram & 2,00, gram \\
\hline Lemak & 34,30 gram & 10,00 gram \\
\hline Karbohidrat & 5.60 gram & 7,60 gram \\
\hline Air & 54,90 gram & 80,00 gram \\
\hline pH & & 6.25 \\
\hline
\end{tabular}

Sumber : Suhardiyono ( 1988 ) dalam IndriaFitri (2000) 


\section{PROSES PEMBUATAN DODOL SUSU}

Untuk membuat dodol susu hendaknya diawali dengan persiapan alat dan bahan yang diperlukan. Peralatan yang digunakan adalah kompor, baskom, santan, pisau, wajan, dan Loyang. Disamping itu bahan-bahan seperti susu cair, santan, tepung beras ketan, gula merah dan gula pasir disiapkan sesuai dengan keperluan. Langkah selanjutnya untuk membuat dodol susu adalah meliputi tahapan sebagai berikut.

\section{Pemilihan bahan Dasar}

Bahan dasar yang digunakan adalah susu cair. Walaupun dalam pembuatan permen caramel dapat menggunakan susu yang tidak segar atau rusak, akan tetapi penggunaan susu segar lebih dianjurkan agar diperoleh hasil yang lebih baik. Hal yang perlu diperhatikan adalah susu tersebut harus mempunyai berat jenis sesuai standar susu yang baik, agar rendemennya cukup besar.

\section{Pemasakan Santan}

Santan kental yang diperoleh dari hasil pemerasan kelapa tua parut dimasak dengan api sedang diaduk-aduk sampai diperoleh santan kenil yang kental dan agak berminyak.

\section{Pemasakan Tepung Beras Ketan}

Sebelum dicampur dengan bahan lain, tepung beras ketan yang digunakan dimasak dengan cara disangrai atau digoreng tanpa minyak dengan api kecil sampai matang dan warnaya agak kuning. Tujuannya agar tepung beras ketan benar-benar matang dan tidak terasa tepung mentah pada hasil akhir.

\section{Pencampuran}

Susu cair, santan kanil, tepung beras ketan sangria, gula merah, gula pasir, garam dan air kapur sirih diukur / ditimbang sesuai kebutuhan.Gula merah ditambahkan air sedikit kemudian dipanaskan sampi gula hancur kemudian disaring. Sedangkan gula pasir dibuat dipanaskan sampai terbentuk caramel dan ditambahkan sedikit air, agar aroma caramel pada dodol susu akan lebih kuat. Kemudian campurkan susu cair, tepung beras ketan, gula merah cair, caramel cair, garam dan air kapur sirih sampai rata. Pencampuran ini bertujuan untuk memudahkan dalam pemasakandan mendapatkan produk hasil terbaik, tidak bergumpal-gumpal dan tidak rata.

\section{Pemasakan}

Bahan-bahan yang telah rata selanjutnya dimasak dengan api sedang sambil diaduk-aduk. Pengadukan selain bertujuan untuk mencampur adonan secara merata, juga berfungsi untuk meratakan panas selama pemasakan. Panas yang tidak merata akan mengakibatkan kematangan adonan yang tidak merata, juga dapat menyebabkan kegosongan pada dasar wajan. Setelah adonan mengental, tambahkan santan kanil dan panaskan kembali, sambil diaduk-aduk. Pemanasan dilakukan sampai adonan matang dengan ciri-ciri kental dan sudah tidak lengket, uji dengan menggunakan solet/spatula plastik, apabila sudah tidak lengket berarti adonan telah matang dan siap untuk dituang kedalam loyang.

\section{Pendinginan}

Selanjutnya dodol yang telah matang dimasukkan kedalam loyang yang telah dioles margarin untuk didinginkan. Pendinginan bertujuan untuk mempermudah pemotongan dan pembungkusan. 


\section{Pemotongan dan Pembungkusan}

Setelah dodol benar-benar dingin, dodol dipotong-potong sesuai selera, kemudian dibungkus dengan plastik. Selanjutnya dodol siap dikonsumsi atau dapat disimpan dalam wadah yang kering, dan dapat juga dikemas lebih lanjut untuk dijual.

\section{DAFTAR PUSTAKA}

Anonimous. 2002. Pelatihan Pengembangan Teknologi Pembuata Karamel, Kerja Sama antara Direktorat Jenderal Bina Pengolahan dan Pemasaran Hasil Pertanian dengan Fakultas Peternakan Universitas Padjadjaran di Kabupaten Garut.
Hidayat Syarief dan adiati S. Dradjat, 1977. Pengetahuan Bahan Hasil Pertanian 1. Direktorat Pendidikan Menengah Kejuruan. Departemen Pendidkan dan Kebudayaan. Jakarta.

Indriafitri Gemelar. 2000. Pengaruh Perbandingan Tepung Beras Ketan dan Jumlah Gula Kelapa terhadap Karkteristik Dodol Durian (Durio zibethinus). Fakultas Teknik, Universita Pasundan, Bandung.

Usman A. Rasjid. 1988. Teknologi Hasil Ternak II. Laporan Praktikum, Fakultas Peternakan Universitas Padjadjaran. Bandung.

Winarmo FG, Srikandi Fardiaz, Dedi Fardiaz. 1980. Pengantar teknologi Pangan, Penerbit PT. Gramedia, Jakarta. 